ks. Jacek Neumann

Wyższe Seminarium Duchowne w Elblagu

DOI: $10.15290 /$ std.2015.01.10

\title{
W NURCIE WYZWAŃ LUDZKIEGO ŻYCIA
}

\section{IN THE STREAM OF NEEDS OF THE HUMAN LIFE}

The contemporary man, and perhaps especially Christian, feels himself torn in to direction. On the one hand, he wants to be a good Christian, and he is moved in the direction of worship, adoration and faith in Christ. On the other hand, he believes in man and man's effort to build up the world, in human progress, in different philosophy and political conception, in human potential to build the future. Both of these directions seem good and deserving of all his effort, but they seem to be two different directions. There is an apparent conflict between the upward impulse of faith, worship, adoration and the forward in the direction of faith only in man, faith in the liberally world, faith in human progress, faith in economy and political philosophy. This apparent conflict between man's upward impulse toward God and his forward impulse toward progress results in a spiritual dualism. Therefore a man in our time will better know himself and reality of the progress of the world in the authentic value of our civilization too. On the way of renovation of his life in the faith's dimension, has a man the possibility to find the motivation to live in the new light of God's love.

Key words: political philosophy, human life, evangelization, faith, Decalogue, God's law, salvation.

Kryterium rozpoznawania, czy też odnajdywania właściwych „dróg szczęścia” każdej ludzkiej istoty, jak i całej społeczności globalnej narodów, w założeniach preferowanej przez dzisiejszy świat „liberalnej koncepcji wyzwolenia człowieka”, znacząco jest związany $z$ kategoriami jedynie immanentnego wartościowania egzystencji opartej zasadniczo na strukturach potrzeb sfery materialnej ${ }^{1}$. Ten

$\overline{1}$ Por. M. A. Peeters, Globalizacja zachodniej rewolucji kulturowej. Kluczowe pojęcia, mechanizm działania, Warszawa 2010, s. 43n. 
zaistniały stan rzeczy wskazuje na zagubiony „gdzieś” w rozreklamowanej konsumpcji świata właściwy zmysł ludzkiego bytu, który w pełni urzeczywistnia się w całym swym duchowym wymiarze jedynie na drodze realizacji pragnień i zamierzeń transcendentalnych ${ }^{2}$. Chociaż znacząco dominuje i w obecnych czasach wysublimowany pęd poszukiwania szczęścia, przyjemności, realizacji doznań i zachwytu nawet za cenę uzależnienia się od psychosomatycznych i farmakologicznych ekstaz, to ostatecznie człowiek dochodzi do wniosku, że wyzbywając się ram Bożych zasad i praw, łatwo się zatraca na rozdrożach egoistycznych racji i mody świata. W konsekwencji zmęczony sobą oraz brakiem szlachetnych i autentycznie wartościowych celów, w paraliżu swawoli i marginalizacji ważnych spraw, traci nie tylko orientację „czasu i miejsca” swego przebywania, ale i całkowicie błędnie zdezorientowany, uwikłany w swe wady i uzależnienia, nie potrafi odczytywać na nowo azymutu dalszego życia ${ }^{3}$. Niejednokrotnie doświadczony porażką życiowych zdarzeń nie czuje się na siłach już dalej rozsądnie i mądrze kształtować swojej przyszłości. Bardziej jeszcze zacierają się właściwe horyzonty ludzkiej egzystencji, gdy człowiek świadomie nie dopuszcza do siebie myśli o istnieniu niezwykłości życia z Bogiem w strukturach uświęcającej łaski. W tym kontekście jakże potrzebna okazuje się chwila zatrzymania ludzkiej myśli na weryfikacji dotychczasowego stylu życia w okowach walki o to, co nie dało i dać nie może wymarzonego szczęścia.

\section{Człowiek w realiach świata}

Człowiek na przestrzeni wielu epok poszukiwał tego, co mogłoby uzdrowić ludzkość z choroby grzechu i śmierci. Jakże więc upragnione, aż do dzisiaj, okazało się pojawienie chrześcijaństwa wraz z darem Zbawienia dokonanym dla człowieka przez Chrystusa. Ono to dało światu rozpadających się imperiów i systemów społeczno-politycznych niezwykłe bogactwo daru wiary, nadziei i miłości, które od ponad dwóch tysięcy lat podtrzymuje kulturę, zwłaszcza europejską, broniąc niezmiennie godności każdego ludzkiego życia.

We współczesnej rzeczywistości świata zdominowanego przez technikę, konsumpcję, hedonizm, liberalizm, relatywizm, dostrzega się coraz bardziej upowszechniające się zjawisko zastępowania monoteistycznych, historycznych religii wiary przez „religię wiedzy” to, że tak wielką siłę wspólnotowej wiary i nadziei stara się zamienić i zastąpić

2 Por. Cz. Rychlicki, Bosko-ludzkie misterium chrześcijaństwa, w: In Persona Christi, K. Góźdź (red.), t. I, Lublin 2009, s. 255-277.

3 Por. Franciszek, Homilia wygłoszona do uczestników Światowego Dnia Młodzieży w dniu 25 VII 2013 w Rio de Janeiro, „L'Osservatore Romano” (dalej: OR) 8-9 (2013), s. 11-12. 
coraz to na nowo „rewitalizowanymi” doktrynami wyimaginowanych idei, które nie sprawdziły się w przeszłości i we współczesnej epoce nadal bardziej degradują ludzką sferę ducha, aniżeli ją odnawiają i wzmacniają. Zadziwiająca jest w tym koniunktura postaw ludzi wierzących, którzy deklarując się jako chrześcijanie w opiniowaniu i przyjmowaniu praw, kodeksów i zasad życia społeczności ludzkich, opowiadają się i „głosują demokratycznie” w sprawach życia społecznego najczęściej negując prawa Boże i Dekalog. Zatem należy postawić pytanie o wiarę tych ludzi, czy ich wiara niejako „zatrzymała się” jedynie na wpisie w parafialne księgi i na metryce chrztu? Także eliminowanie modlitwy, zwłaszcza z życia rodziny, wskazuje na zanik trwania człowieka w duchu jedności z Bogiem. Widzialnym tego skutkiem jest degradacja duchowych wartości w kształtowaniu człowieka, naznaczonego przecież znamieniem godności dziecka Bożego. Tak jak w chwilach zadumy nad zanikiem chrześcijańskiego ducha na przestrzeni historii, tak i dzisiaj należy wniknąć w głębię ludzkich motywacji, którymi kieruje się człowiek w swoich poczynaniach codziennego życia w separacji od Boga, z żalem do Niego, a niejednokrotnie i w złości na $\mathrm{NiegO}^{5}$.

Od strony merytorycznej człowiek jako fenomen osoby ludzkiej jest ze swej natury jedyną w swym wymiarze rzeczywistością. O jego stronie metodologicznej zaś decyduje rozum i myślenie. Zestawiając ze sobą te dwie relacje należy uznać, że człowiek jest „rzeczywistością rzeczywistości”, światem świata. Nie sposób nie dostrzec ze sposobu „zachowania się” człowieka, że jest on nie „czymś”, ale „kimś” znamiennym, „kimś” danym bezpośrednio i zarazem dostępnym tylko pośrednio, „kimś” widzialnym i „kimś” niewidzialnym, „kimś” znanym i nieznanym, „kimś” ciągle doświadczanym i zarazem wykraczającym poza doświadczenia. Dlatego człowiek kontempluje, bada, myśli, doświadcza i tworzy nauki o sobie. I to go stawia w pierwszym szeregu stworzeń „kimś drugim" po Bogu. A jako osoba jest podobny do Boga w miłowaniu, pracy, stwarzaniu, wolności wyrazu i działaniu, w administrowaniu światem ${ }^{6}$.

Człowiek jest taki sam, ale jest inny. Ma inne życie, inny charakter, inny los, inny wygląd. W relacjach z innymi ma swoje życie, ale z innymi wspólnie żyje, wspólnie myśli, ma wspólne serce, wspólne działanie. Człowiek ma wymiar moralny, ma w sobie szkic swej przyszłości zakodowany w transcendencji. Jednak ze względu na fakt, że osoba ludzka nie jest Boską, dlatego odczuwa w sobie ból rozdarcia na wielkość i małość, na dobroć i złość, na niebo i piekło,

$5 \quad$ Por. Benedykt XVI, W czasach kryzysu potrzebujemy relacji opartych na bezinteresowności i mitości. Przemówienie do przedstawicieli władz cywilnych $i$ wojskowych z dnia 6 VI 2012, OR 7-8 (2012), s. 11-12.

6 Por. idem, Podsycajcie zamitowanie do prawdy. Przemówienie do uczestników kongresu wydziatów medialnych uczelni katolickich z dnia 23 V 2008, OR 7-8 (2008), s. 10-11. 
na świętość i grzech. To skłania człowieka do realizacji swego jestestwa poprzez fundamentalne prawo walki wewnętrznej i zewnętrznej, między prawdą i fałszem, dobrem i złem ${ }^{7}$. I na te elementarne uwarunkowania ludzkiej egzystencji należałoby w różnorodnych procesach formacyjno-edukacyjnych człowieka, coraz bardziej zwracać uwagę rozpoznając i eliminując zagrożenia docierające do ludzkiej świadomości ze strony współczesnego „zawirusowanego świata”. Nie bez znaczenia jest więc i w tym procesie moc oddziaływania Kościoła w darze świętych sakramentów przywracających harmonię życia człowieka z Bogiem i bliźnim. Życiu ludzkiemu „rozregulowanemu” przez grzech nie jest nikt ze stworzeń w mocy ponownie przywrócić charakter porządku moralnego i duchowej harmonii. Ten „zablokowany kod stwórczy” nikt, poza Bogiem, nie jest w stanie rozeznać i ponownie go aktywizować. Dlatego w Chrystusie Bóg dał światu „kod zbawczy” wpisany w Jezusa, który poprzez dzieło Odkupienia i zbawczą Mękę ofiaruje człowiekowi prawdziwe życie9

Mając na względzie te aspekty troski o człowieka dzisiejszych czasów, należy w pracy formacyjno-edukacyjnej, duszpasterskiej, opiekuńczo-wychowawczej, socjalnej, uwzględniać antropologiczny wymiar ludzkiego istnienia. To pozwoli rozeznać wartość osoby ludzkiej i jej godność, pozwoli określić miejsce człowieka w realiach życia środowiskowego, jego urzeczywistnianie się w tworzeniu kultury i tradycji lokalnej społeczności, realizowanie powołania do świętości i zbawienia siebie i innych. Człowiek posiada rozum, co się wiąże z poznaniem, funkcjonowaniem umysłu, wyzwalaniem intuicji, doznaniem i tworzeniem duchowym. W wymiarze posiadanej woli człowiek wyraża swoje dążenia, podejmuje decyzje, dokonuje wyborów, samookreśla się w różnorodnych sytuacjach życiowych, kieruje się ku takim wartościom jak wolność, suwerenność, moralność, sprawiedliwość, prawda, dobro, miłość, wiara. Nie można w tym wymiarze antropologicznym pominąć faktu, że człowiek istnieje. I nawet, gdy przekracza granicę biologicznej śmierci, to nadal żyje, chociaż już w innych strukturach bytu, czego dowodem jest jego kultura zapisana w tradycjach kultu, obrzędach, rytuałach, sztuce, liturgii, mitologii, religii. Człowiek istnieje zawsze jako rzeczywistość, jako substancja egzystująca konkretnie w misteryjnym wymiarze istnienia (existere), działania (actus), sprawności (operari). Zatem jest on wobec otaczającego świata czynny i bierny, jest podmiotem i przedmiotem, jest istnieniem $\mathrm{w}$ wymiarze absolutnym wkomponowanym $\mathrm{w}$ struktury ciała

7 Por. J. Grabowski, Budowa przyszłości czlowieka i narodu na tradycji i dziedzictwie, w: Ku zmartwychwstaniunarodu. Wykłady inauguracyjne 2010/2011, S. Urbański (red.), Warszawa 2010, s. 27-39.

8 Por. A. Sajdak, Edukacja kreatywna, Kraków 2008, s. 47n.

9 Por. J. Lewandowski, Bóg $i$ człowiek, Warszawa 2001, s. 35n. 
i duszy, aż do transcendencji bytu i pewnej samotranscendencji ${ }^{10}$. Dlatego posiada on swoją „głębię”, swoje istnienie, swoją historię urzeczywistniającą się w sposobie życia w różnorodnych koniunkturach jak duchowa, moralna, dążeniowa, dziejowa czy futurystyczna. To przemawia za tym, że człowieka cechuje istnienie w sobie i w świecie zewnętrznym, że jest on "kimś osobnym” i zarazem „kimś wspólnotowym”, że rozwija się sam w sobie i w relacjach do innych osób, że staje się sobą i funkcjonuje najpełniej poprzez odniesienie do innych. To przemawia za tym, że niezwykle ważne w procesie kształtowania ludzkiej osobowości staje się właściwe rozeznanie i zrozumienie antropologicznych aspektów ludzkiej egzystencji w konfrontacji z wyzwaniami współczesnej człowiekowi epoki ${ }^{11}$.

\section{Powołanie człowieka do Zbawienia}

Kościół od wieków z wielkim duchem troski przekonywał świat o życiu w jedności z Bogiem. Także i w dzisiejszych czasach skłania świat gubiący się w swoich wyimaginowanych „na jawie” ideologiach, by powrócił na drogę życia z Bogiem, by odkrył na nowo prawdziwą godność człowieka powołanego do Zbawienia, by zachował wszystko, co służy świętości małżeństwa i rodziny, by docenił ekumenizm ogólnoludzki, by respektował cywilizację życia, a nie zgadzał się na ukonstytuowanie propagowanej z wielką siłą przez wrogów życia cywilizacji śmierci, by doceniał prymat kultury duchowej nad techniką, osoby nad rzeczą, pracy nad towarem, by rozpoznał absolutny sens prawdy wszelkich dążeń ludzkich w działaniu na rzecz autentycznej troski o człowieka ${ }^{12}$. W katalogu wielu niepokojących przemian i przeobrażeń społeczno-kulturowych oraz ekonomiczno-politycznych wibracji obecnych czasów, daje się odczytać niepokojący stan kondycji naszej epoki owianej wprawdzie hasłami humanizmu, relatywizmu, liberalizmu, konsumpcjonizmu, to jednak nieurzeczywistniającego prawdziwego zachwytu i „pogodnej przyszłości” obecnej generacji i także następnych pokoleń ${ }^{13}$. W takim to oddziaływaniu świata na człowieka i jego styl życia w różnorodnych społecznościach ludzkich, człowiek łatwo zatraca azymut swego dążenia do szczęścia, popada w dezorientację o kierunku marszu sugerowanym mu przez coraz to nowe wzajemnie wykluczające się

10 Por. S. Ewertowski, Transcendencja ludzkiej osoby, w: Veritas Christi liberat, P. Rabczyński (red.), Olsztyn 2014, s. 187-202.

11 Por. J. Galarowicz, Cztowiek jest osoba. Podstawy antropologii filozoficznej K. Wojtyty, Kęty 2000 , s. 73 n.

12 Por. Jan Paweł II, Wspótpracować w szerzeniu Królestwa Bożego na świecie. Przemówienie na audiencji generalnej z dnia 6 XII 2000, OR 3 (2001), s. 37-38.

13 Por. K. Korab, Czy nowy wspaniały świat?, Warszawa 2010, s. 62n. 
i zaprzeczające sobie przekazy pseudoideologów, władców areny politycznej, majętnych i zasobnych w wielkie możliwości dealerów uzależnień. Dobrze, gdy człowiek kierując się mądrością rozumu i katalogiem Bożych wskazań Dekalogu będzie w stanie sprostać dewastacji swego sumienia, a mocą swej woli będzie miał siły zachować w sobie pragnienie życia „nutą dobra, prawdy i piękna”. W przeciwnym wypadku stawać się będzie istotą niezmiernie ubogą, zagubioną, żyjącą w zawieszeniu między niezdolnością stawiania czoła teraźniejszości a lękiem przed przyszłością, istotą dręczoną egoizmem i słabościami natury ${ }^{14}$. Niejednokrotnie stając w obliczu takiego „przewartościowania” swego życia, człowiek nie potrafi już zadać sobie pytania o najbardziej autentyczny sens swej egzystencji i o możliwość odczytania znaków na drodze ewakuacji wyjścia z niebezpiecznych zagrożeń. Zapewne dochodzą do niego jeszcze może jakieś myśli „kalkulowania życiem”, ale najczęściej już coraz bardziej interesuje go i absorbuje tylko „działanie” oparte na programowaniu swego „panowania”. Do tego stanu uzależnienia się człowieka od „kombinacji życia i życiem” prowadzi swoisty racjonalizm techniczno-naukowy, wysublimowany relacjonizm, „pseudozaradczy” liberalizm, które poprzez swoją dominację we współczesnej kulturze, odrzucając ideę prawdy o stworzeniu i o Bogu, wkładają na człowieka szaty iluzji i koronę tęczy. W konsekwencji jednak życia bez Boga, bez sumienia, bez uczciwości i sprawiedliwości, szata staje się bardzo szybka wyblakła i zbutwiała, a wielobarwna korona traci kolory, stając się splotem cierni. W takiej reklamie życia ,jakby Stwórca nie istniał”, człowiek zatraca nie tylko tajemnicę Boga, ale również tajemnicę świata i swego istnienia. Ostatecznie osłabienie więzi z Bogiem i $z$ drugim człowiekiem prowadzi nieuchronnie do materializmu praktycznego, opartego wyłącznie na kategoriach wydajności ekonomicznej, atrakcji i przyjemnościach ${ }^{15}$.

Człowiek poszukując prawdziwego sensu swojego życia staje przed rzeczywistością dokonujących się przeobrażeń świata. Nie bez znaczenia jest więc dla człowieka ateizm czy sekularyzacja, które „pozornie” uszczęśliwiają ludzkość16. W tej nowej rzeczywistości zderzenia się dwóch światów - Bożego i ziemskiego, człowiek ulega niejednokrotnie determinacji i zatraca jasny sens religijnego życia gubiąc się w katalogu prowokacyjnych haseł. Mając to na względzie konieczne staje się odkrycie na nowo Boga w Duchu i Prawdzie (J 4, 24). Ta sposobność powrotu do źródła życia jest w stanie dokonać w człowieku otwarcia

14 Por. Jan Paweł II, Wartości religijne i moralne wspólnym dziedzictwem. Przemówienie do uczestników Konferencji Ministrów Rady Europy w dniu 3 XI 2000, OR 1 (2000), s. 47-48.

15 Por. idem, W stużbie cywilizacji mitości. Przemówienie na audiencji generalnej z dnia 23 VIII 2000, OR 10 (2000), s. 6-7.

16 Por. Z. Grocholewski, Uniwersytety wobec wspótczesnych wyzwań, Warszawa 2013, s. 15n. 
się na fakt nowego narodzenia się w nim Chrystusa ${ }^{17}$. Zatem przez urzeczywistnienie motywu potrzeby religijnej człowieka i realizacji aspiracji wobec tajemnicy niezbadanych zamierzeń Boga, staje człowiek w prawdzie o sobie samym i swym przeznaczeniu. Odnajdując Boże wartości, urzeczywistnia on tajemnicę swego powołania do świętości, a doświadczając tego daru dochodzi do poznania swego "miejsca i czasu” w wydarzeniach historii Zbawienia ${ }^{18}$.

Znamiennym wezwaniem dla człowieka współczesnej epoki jest odkrycie „obecności Boga w naszych czasach” ${ }^{19}$. To wymaga koncentracji ludzkiego spojrzenia na Oblicze Boga, Stwórcy świata ${ }^{20}$. Dzięki weryfikacji i ocenie różnych propozycji świata człowiek rozpoznaje „zamysł Boży - drogowskaz” na bezdrożach świata. Poprzez ten dar spotkania z Bogiem na drodze sakramentalnej odnowy „otwierają się człowiekowi oczy”, którymi jest on w stanie dostrzec sens dokonanego przez Chrystusa dzieła Zbawienia. Tak jak Chrystus stoi na drogach świata $z$ darem krzyża i Zmartwychwstania, tak człowiek w cieniu krzyża i w blasku Zmartwychwstania odzyskuje utraconą przez grzech godność dziecka Bożego i dziedzictwo Królestwa Niebieskiego. To uświadamia człowiekowi, kim jest, dokąd zmierza i co go czeka. By człowiek przekonał się do Boga i by przyjął to, co mu Bóg ofiaruje, Chrystus stał się Człowiekiem. Ten nowy sposób objawienia się Boga inspiruje człowieka do większego zaufania i zawierzenia Bogu. W takiej rzeczywistości staje się widzialne działanie Boga w procesie duchowo-moralnej odnowy ludzkiego życia na drodze sakramentalnego uświęcenia ${ }^{21}$.

Bóg, który powołuje każdego człowieka do udziału w owocach Odkupienia, obdarza go swoją łaską i mocą, a udzielając człowiekowi swego przebaczenia, powierza mu zarazem misję bycia „zaczynem” pokoju i pojednania w otaczającym go środowisku. To przyczynia się do odzyskania i rozbudzenia w człowieku entuzjazmu wiary, dzięki której każdy chrześcijanin doświadcza radości ze spotkania z Chrystusem ${ }^{22}$. W efekcie pozwala to człowiekowi wiary trafnie odczytywać to, co jest dobrem i prawdą we współczesnym świecie i jednocześnie

$17 \quad$ Por. Jan Paweł II, Incarnationis misterium. Bulla ogłaszająca Wielki Jubileusz Roku 2000 (dalej: IM), Watykan 1998, n. 51.

18 Por. Cz. Bartnik, Personalizm, Lublin 2008, s. 276n.

19 IM, n. 3.

20 Por. Jan Paweł II, Jezus Chrystus jest petnia całego objawienia. Przemówienie do uczestników sesji plenarnej Kongregacji Nauki Wiary z dnia 28 I 2000, OR 3 (2000), s. 40-41.

21 Por. idem, Pojednajcie się z Bogiem. Homilia w czasie Mszy św. w bazylice św. Sabiny z dnia 28 II 2001, OR 4 (2001), s. 23.

22 Por. idem, Serce Chrystusa zawsze otwarte dla wszystkich. Homilia w czasie Uroczystości Objawienia Pańskiego i Zamknięcia Wielkiego Jubileuszu Roku 2000 z dnia 6 I 2001, OR 2 (2001), s. 52-54. 
rozpoznawać zagrożenia, które niszczą dotychczas niejednokrotnie z trudem zachowywany depozyt chrześcijańskiej wiary. Dlatego obok koniecznych środków do godziwego życia winno się przywrócić na nowo w hierarchii dóbr dzisiejszego świata wartość wiary, nadziei i miłości. Realia rzeczywistości i różne filozofie życia sprawiają, że coraz bardziej staje się widoczne odejście nie tylko od tego, co Bóg w dziele stworzenia „uczynił jako dobre”, lecz również „wzmaga się walka" z tym, co Boże i święte. To pociąga za sobą w konsekwencji postawę obojętności religijnej człowieka, który „rodzi się bez miłości, żyje bez wiary i umiera bez nadziei"23. Nadto rozpropagowana nie tylko medialnie negacja chrześcijaństwa i nienawiść do wiary katolickiej, zbiera żniwo krwawego prześladowania z wielkim już katalogiem męczenników XXI wieku.

Poszukiwanie Boga jest poszukiwaniem wciąż odnawianym, opartym na radości, że się odnalazło. Tłumy, które odnalazły Jezusa nie zatrzymały się, ale szły za Nim, by być już zawsze w Jego obecności, by uważnie za Nim iść tak, by się zbytnio nie oddalił. W tym kontekście mówi Jezus do Marii Magdaleny, gdy ta płacze nad Jego grobem: „Niewiasto, czemu płaczesz? Kogo szukasz?” (J 20, 15). Jezus pomaga Marii szukać, chociaż już tam jest. Chrystus zawsze działa w ten sposób. „Znalezienie” realizuje się w nowym „poszukiwaniu”.

\section{Odnowa duchowo-moralna człowieka}

Obok wielu istniejących niepokojów o dzisiejszego człowieka, ma miejsce w życiu ludzkim znamienny optymizm jak wiara w możliwości człowieka, który jest zdolny poznać prawdę o Bogu, rozeznać dobro i je wybrać. Istotą chrześcijańskiego optymizmu jest fakt, że Bóg stworzył człowieka do miłości. Chociaż w lansowanym medialnie tzw. normalnym świecie coraz głośniej mówi się o miłości, którą sprowadza się najczęściej do zmiennej sfery prywatnych doznań, to jednak każdy człowiek odpowiadając na wezwanie Boga, uświadamia sobie swą transcendentną godność i odbudowuje swe przekonanie, że jest stworzony do miłości na wzór Boży.

Aby odbudować i stworzyć nowy solidarny i sprawiedliwy świat, potrzeba odnowionego zrywu ewangelizacyjnego, który winien obejmować różne sfery społeczeństwa: kulturę, sztukę, politykę, ekonomię, środki społecznego komunikowania się, zdrowie, sport ${ }^{24}$. W imię „nowej ewangelizacji” trzeba przepowiadać miłość Boga, który stworzył człowieka na swój obraz i podobieństwo, i odkupił go w Chrystusie. Bóg wymaga przywrócenia sprawiedliwości i przebaczenia jako podstawowej reguły wszelkich relacji międzyludzkich, a kluczem

23 Por. Comiteto Centrale del Grande Giubileo dell'Anno 2000, Diario di un evento di fede, Città del Vaticano 2001, s. 38n.

24 Por. J. Ratzinger, Voici quel est notre Dieu, Paryż 2000, s. 309n. 
takiego podejścia do cywilizacji i historii jest Chrystus ${ }^{25}$. Teraźniejszość potrzebuje Boga, by poznać podstawową prawdę o człowieku i jego godności jako dziecka Bożego. Dlatego Bóg posłał swego Syna, aby człowiek się przekonał o tym, czym pragnie go Bóg obdarzyć w wieczności i żeby człowiek wsparty łaską miał moc wypełnić tajemniczy zamysł Bożej miłości.

Szacunek dla człowieka - owoc żywej wiary, miłości i chrześcijańskiej kultury staje dzisiaj przed ludzkością jako wielkie zadanie. Gdyby respektowano godność człowieka, nie dochodziłaby do głosu kultura śmierci, przemocy i bezlitosnej konkurencji, nie byłoby plagi seksualizmu, która niszczy miłość, nie byłoby tylu zagubionych młodych ludzi sięgających po alkohol i narkotyki, nie byłoby eutanazji i odrzucenia osób starszych, chorych, niepełnosprawnych. Jeżeli człowieka obdarzy się należną mu godnością, jeżeli człowiek zachowa prawe sumienie $\mathrm{w}$ swoim postępowaniu, w rodzinie, w pracy, w życiu społecznym i ekonomiczno-politycznym, wówczas poprawi się byt człowieka. Dlatego potrzeba nowego stylu myślenia, prawego wychowania, właściwego kształtowania świadomości od dzieciństwa ${ }^{26}$.

Człowiek współczesny, zwłaszcza młody, zanurzony w świecie bogactw lub pogrążony w nędzy wynikającej z niesprawiedliwego kształtu życia społecznego, szuka autentycznych wartości, jest otwarty na bogactwa duchowe, na wszystko to, co jest ponad nim. Najkrócej mówiąc, pragnie odnaleźć ślady obecności Boga. A najlepszym przewodnikiem w tym poszukiwaniu Boga jest prawe sumienie. Każdemu człowiekowi jest potrzebny przewidziany w planie Bożym ideał człowieczeństwa, a wskazując na chrześcijaństwo i wiarę dostrzega się w nich dopełnienie i uwieńczenie ludzkiej osobowości. Nadto związanie się z Chrystusem rozszerza i podnosi dążenia człowieka ${ }^{27}$. Także wszelka twórczość kulturowa idąca na pomoc ludzkiemu życiu musi przede wszystkim inspirować odnowę porządku moralnego niszczonego przez „chaos moralny”. Przejawem silnie reklamowanego marketingowo „chaosu moralnego” jest egoizm, posługujący się manipulacją i negacją prawdy. Przedstawia on skrajny indywidualizm jako konsekwencję wolności zasługującą na pochwałę. W przestrzeni tego „chaosu” świętość i altruizm są przemilczane, wyśmiewane bądź kompromitowane. Zaistnienie „chaosu moralnego” na szerokiej płaszczyźnie kulturowej staje się dostrzegane poprzez lansowanie kultu tzw. jakości życia oraz stawianie tejże „jakości” ponad świętość życia. W praktyce takiej głosi się kult tężyzny fizycznej i zalet biologicznych, a lekceważy się wielkość człowieka wyrażoną

25 Por. W. Kasper, Kościót Katolicki. Istota. Rzeczywistość. Posłannictwo, Kraków 2014, s. 64-66.

26 Por. M. J. Dyrda, A. Świderski, Rozwój osobowy i jego zagrożenia, Siedlce 2003, s. 38n.

27 Por. H. Gulbinowicz, Wokót teologii osoby, w: In Persona Christi, K. Góźdź (red.), Lublin 2009, t. II, s. 787-795. 
w jego zmaganiach $z$ cierpieniem i słabością fizyczną. Tymczasem świadomy swej godności człowiek nie musi uciekać od cierpienia za wszelką cenę, gdyż przykład Chrystusa uczy go odkrywać właściwy sens w cieniu krzyża ${ }^{28}$. Nie wolno więc bagatelizować dramatycznych zmagań z cierpieniem podejmowanych przez wielu ludzi i nie wolno zapominać, że to właśnie w ludzkim dążeniu do świętości w decydujący sposób wyraża się troska o „prawdziwą jakość życia”. Wobec obojętności wielu ludzi względem prawego życia opartego na Ewangelii, czynnikiem dającym pewne szanse na „uzdrowienie człowieka” jest roztropne wnikanie w treść problemów ludzkich i zaangażowanie chrześcijańskie w ich rozwiązywanie. Wielką rolę spełnia w tym procesie właściwe spojrzenie na wiarę, sakramenty i życie moralne. Chodzi nie tyle o to, aby tych, co odeszli od wiary i zdystansowali się od Kościoła, z powrotem do wiary przyprowadzić. Oni zazwyczaj nie słuchają wezwań. Trzeba jednak wychodzić im naprzeciw i pozwolić, aby mogli swój świat idei i poglądów oraz postawy życiowe skonfrontować z chrześcijańskim orędziem przekazywanym w życiu. Tak postępował Jezus w swym nauczaniu. Święty Jan Paweł II w jednej ze swych środowych katechez powiedział:

Przemawiając do rzesz, Jezus posługuje się przypowieściami, dostosowując w ten sposób swoją naukę do umysłowości słuchaczy. Stopniowo wyjaśnia ją uczniom, uwzględniając ich trudności w zrozumieniu i dopiero w drugim okresie życia publicznego otwarcie zapowiada swoją bolesną drogę, po czym na końcu wyjawia im swoją tożsamość nie tylko Mesjasza, ale także Syna Bożego. Stwierdzamy również, że w szczególnie ważnych dialogach przekazuje treść swego Objawienia, odpowiadając na pytania rozmówców i posługując się dostępnym dla nich językiem. Czasem sam zadaje pytania, ukazuje problemy ${ }^{29}$.

Według Papieża, ewangelizacja wiele traci na swej mocy i wpływie, jeżeli nie uwzględnia charakteru ludzi, do których się zwraca, jeśli nie odpowiada na stawiane przez nich pytania, jeśli wreszcie nie dotyczy i nie porusza ich rzeczywistego sposobu życia. Dlatego ważnym staje się odnowienie w każdym wierzącym swojej wiary, by następnie na kanwie przeżyć korygować własne życie i pomagać innym, zwłaszcza zagubionym, w odnalezieniu poszukiwanego autentycznego szczęścia.

\section{Człowiek na drodze wiary}

Chrystus nadaje misji Kościoła wymiar odpowiedniego rozeznania i urzeczywistnienia tych idei, które znacząco wpływają na realizowanie się zamierzeń egzystencjalnych człowieka w aspekcie wiary. Potrzeba ich zrozumienia staje

28 Por. Benedykt XVI, Jezus z Nazaretu, Kraków 2007, t. I, s. 51-64.

29 Jan Paweł II, Wartość zaangażowania w rzeczywistość doczesna. Przemówienie na audiencji generalnej w dniu 13 XII 2000, OR 3 (2001), s. 38-39. 
się wymogiem w procesie właściwego zaakceptowania tego, co służy rozwojowi człowieczeństwa. Jednak współczesny kryzys wiary dokonuje w stylu życia chrześcijanina bardzo newralgiczną obojętność religijną. Pojawia się konieczność podejmowania prób ożywienia wiary i dania o niej konkretnego świadectwa. Kościół wskazując na wartość chrześcijańskiej wiary, prezentuje działanie Boga Ojca:

W Jezusie Chrystusie Bóg nie tylko mówi do człowieka - Bóg szuka człowieka.

Wcielenie Syna Bożego świadczy o tym, że Bóg szuka człowieka [...]. Jeśli Bóg wychodzi na poszukiwanie człowieka [...] to dlatego, że go miłuje ${ }^{30}$.

Kościól, w którym można doświadczać bardziej „z bliska” obecności Boga, pomaga poszukującemu człowiekowi rozeznawać przeżywane doświadczenia związane zarówno $z$ grzechem, jak i konfrontować swoje życie w ramach Bożego Miłosierdzia. Doświadczany dar łaski Bożej w postawie nawrócenia i powrotu do życia wiarą, sprawia w człowieku przeżywanie niejako do głębi przenikającego uzdrowienia i uświęcenia. Na to przeobrażanie się człowieka uwrażliwia w swej misji Kościół, który troszczy się ze wszystkich stron o odnowę życia człowieka, by mógł on „oczyścić serce” i dostrzec oczyma wiary łaskę Boga przywracającą nadzieję prawdziwego życia w jedności z Bogiem. To skłania człowieka do twórczych przemyśleń nad darem otrzymanego chrztu św. i bierzmowania oraz jest sposobnością zrozumienia istoty wiary, niewidzialnej dla oczu, ale dostrzegalnej czy rozumianej przez „serce”. W ostatnich latach w przesłaniu Kościoła została wyraźnie zaakcentowana myśl ponownego odkrycia centralnego miejsca Jezusa Chrystusa w życiu człowieka. „Słowo stało się ciałem i zamieszkało wśród nas” (J 1, 14). „W Nim mamy odkupienie przez Jego krew - odpuszczenie występków, według bogactwa Jego łaski. Szczodrze ją na nas wylał w postaci wszelkiej mądrości i zrozumienia” (Ef 1, 7). Te biblijne przekazy uświadamiają ludziom naszych czasów, że wiara chrześcijańska nie bazuje na filozoficznej idei, ale na Osobie Jezusa Chrystusa ${ }^{31}$. To skłania człowieka do przyjęcia „projektu życia”, który nie oddziela ludzkiego istnienia od Boga, ale w Nim znajduje pełne uzasadnienie i godność. Znamiennym potwierdzeniem tego jest konfrontacja ludzkiego życia z tym, co niesie w sobie Chrystus. To przekonuje, że człowiek przeżywając swoje słabości i grzechy, ma możność podejmując w pokorze przed Bogiem trud nawrócenia i przemiany, odrestaurować swoje „jestestwo” i w przyjęciu Bożego Miłosierdzia rozwijać swoje człowieczeństwo.

$30 \quad$ Jan Paweł II, List apostolski Tertio millenio adveniente, Watykan 1994, n. 7.

31 Por. Aparecida. V Ogólna Konferencja Episkopatów Ameryki Łacińskiej i Karaibów. Dokument końcowy. Jesteśmy uczniami i misjonarzami Jezusa Chrystusa, aby nasze narody mialy w Nim życie, Kraków 2014, s. 65n. 
Słowa klucze: filozofia polityczna, życie ludzkie, ewangelizacja, wiara, Dekalog, prawo Boże, Zbawienie.

\section{Bibliografia:}

1. Aparecida. V Ogólna Konferencja Episkopatów Ameryki Łacińskiej i Karaibów. Dokument końcowy. Jesteśmy uczniami i misjonarzami Jezusa Chrystusa, aby nasze narody mialy w Nim życie, Kraków 2014.

2. Bartnik Cz., Personalizm, Lublin 2008.

3. Benedykt XVI, Jezus z Nazaretu, Kraków 2007, t. I.

4. Benedykt XVI, Podsycajcie zamilowanie do prawdy. Przemówienie do uczestników kongresu wydziałów medialnych uczelni katolickich z dnia 23 V 2008, „L'Osservatore Romano" 7-8 (2008).

5. Benedykt XVI, W czasach kryzysu potrzebujemy relacji opartych na bezinteresowności $i$ mitości. Przemówienie do przedstawicieli wtadz cywilnych $i$ wojskowych z dnia $6 \mathrm{VI}$ 2012, „L'Osservatore Romano” 7-8 (2012).

6. Comiteto Centrale del Grande Giubileo dell'Anno 2000, Diario di un evento di fede, Città del Vaticano 2001.

7. Dyrda M. J., Świderski A., Rozwój osobowy i jego zagrożenia, Siedlce 2003.

8. Ewertowski S., Transcendencja ludzkiej osoby, w: Veritas Christi liberat, P. Rabczyński (red.), Olsztyn 2014.

9. Franciszek, Homilia wygtoszona do uczestników Światowego Dnia Młodzieży w dniu 25 VII 2013 w Rio de Janeiro, „L'Osservatore Romano” 8-9 (2013).

10. Galarowicz J., Czlowiek jest osoba. Podstawy antropologii filozoficznej K. Wojtyty, Kęty 2000.

11. Grabowski J., Budowa przysztości człowieka i narodu na tradycji i dziedzictwie, w: Ku zmartwychwstaniu narodu. Wykłady inauguracyjne 2010/2011, S. Urbański (red.), Warszawa 2010.

12. Grocholewski Z., Uniwersytety wobec wspótczesnych wyzwań, Warszawa 2013.

13. Gulbinowicz H., Wokót teologii osoby, w: In Persona Christi, K. Góźdź (red.), Lublin 2009, t. II.

14. Jan Paweł II, Incarnationis misterium. Bulla ogłaszająca Wielki Jubileusz Roku 2000, Watykan 1998.

15. Jan Paweł II, Jezus Chrystus jest petnią całego objawienia. Przemówienie do uczestników sesji plenarnej Kongregacji Nauki Wiary z dnia 28 I 2000, „L'Osservatore Romano” 3 (2000).

16. Jan Paweł II, List apostolski Tertio millenio adveniente, Watykan 1994.

17. Jan Paweł II, Pojednajcie się z Bogiem. Homilia w czasie Mszy św. w bazylice św. Sabiny z dnia 28 II 2001, „L'Osservatore Romano” 4 (2001).

18. Jan Paweł II, Serce Chrystusa zawsze otwarte dla wszystkich. Homilia w czasie Uroczystości Objawienia Pańskiego i Zamknięcia Wielkiego Jubileuszu Roku 2000 z dnia 6 I 2001, „L'Osservatore Romano” 2 (2001). 
19. Jan Paweł II, Wartości religijne i moralne wspólnym dziedzictwem. Przemówienie do uczestników Konferencji Ministrów Rady Europy w dniu 3 XI 2000, „LOsservatore Romano" 1 (2000).

20. Jan Paweł II, Wartość zaangażowania w rzeczywistość doczesna. Przemówienie na audiencji generalnej w dniu 13 XII 2000, „L'Osservatore Romano” 3 (2001).

21. Jan Paweł II, W stużbie cywilizacji miłości. Przemówienie na audiencji generalnej z dnia 23 VIII 2000, „L'Osservatore Romano” 10 (2000).

22. Jan Paweł II, Wspótpracować w szerzeniu Królestwa Bożego na świecie. Przemówienie na audiencji generalnej z dnia 6 XII 2000, „L'Osservatore Romano” 3 (2001).

23. Kasper W., Kościót Katolicki. Istota. Rzeczywistość. Posłannictwo, Kraków 2014.

24. Korab K., Czy nowy wspaniaty świat?, Warszawa 2010.

25. Lewandowski J., Bóg i czlowiek, Warszawa 2001.

26. Peeters M. A., Globalizacja zachodniej rewolucji kulturowej. Kluczowe pojęcia, mechanizm działania, Warszawa 2010.

27. Ratzinger J., Voici quel est notre Dieu, Paryż 2000.

28. Rychlicki Cz., Bosko-ludzkie misterium chrześcijaństwa, w: In Persona Christi, K. Góźdź (red.), t. I, Lublin 2009.

29. Sajdak A., Edukacja kreatywna, Kraków 2008.

30. Tischner J., Idąc przez puste Błonia, Kraków 2014. 